\title{
Efficacy of Different Methods Applied Separately and in Combination for Controlling Root-Knot Nematode M. javanica on Cucumber
}

\author{
Sulaiman Naif Ami*, Shireen Ghaeib Ali Shingaly \\ Department of Plant Protection, College of Agricultural Engineering Sciences, University of Duhok, Duhok, Kurdistan Region - \\ Iraq, (sulaiman.ami@uod.ac, ali.shingaly@uod.ac) \\ *Correspondence: sulaiman.ami@uod.ac
}

\begin{abstract}
Results of the use of various control methods (Chemical, Biological, Systemic Acquired Resistance (SAR) and Ethanol Extract of Chili Pepper ) individually or in combination showed improvement in all growth criteria of cucumber plants grown in soil infested with $M$. javanica eggs including length, dry and fresh weight of root and shoot system with chlorophyll content of leaves and strong reduction in infection criteria. The use of bio-health one week after Vydate as integrated control was found to be one of the most effective treatment compared to other treatments by improving all growth criteria of cucumber plants. On the other hand, the same treatment excelled in its effect on the other treatments where the highest reduction in infection criteria including number of galls, root gall severity, number of egg masses, number of nematode in root system, number of nematode in soil pot, number of eggs, final population density of nematode and reproduction rate of nematode in cucumber plants grown in infested soil as compared with control treatment (infested soil).The results also indicated that the less effective treatment was ethanol extract from chili pepper fruit in increasing cucumber growth criteria or reducing infection criteria.
\end{abstract}

Keywords: M. javanica, Chemical control, Biological control, Systemic Acquired Resistance, Integrated Control, Cucumis sativus

Received: June $16^{\text {th }}, 2020 /$ Accepted: September $3^{\text {rd }}, 2020 /$ Online: September $20^{\text {th }}, 2020$.

\section{INTRODUCTION}

Root-knot nematodes are dangerous and economically very important pest of most cultivated crops in the world (Hussain et al. 2011).They are harmful nematodes for plants and considered as one of the main limiting factor effects on plant growth and yield which cause about $\$ 100$ billion loss per year worldwide (El-Sayed and Mahdy, 2015).

Root-knot nematode M. javanica, causes various damage to huge number of plant species including Cucurbitaceae family (Azam et al., 2010).Various plant part extracts have been recorded to be toxic to many nematodes including Meloidogyne species (Montasser et al., 2012). Chemical control has been found to be the important strategy to reduce root-knot nematodes (Seid et al., 2015). Bio-control agents used as a measure of nematodes control is now being broadly developed and several of them are previously being produced commercially (El-Zawahry et al., 2015).
Bio-control agents consist of different microorganisms (fungi, bacteria, algae, viruses or protozoa) as an active ingredient often referred to microbial pesticides (Arora et al., 2000). Salicylic acid (SA) is a natural phenolic compounds exists in many plants and involved in induction of resistance in different plants (Ohri and Pannu, 2010), whereas it may have an inhibiting effect on the nematode reproduction index (Molinari and Loffredo, 2006).

The combination of two or more control methods is the only sound sustainable approach to manage root-knot nematodes effectively (Khan et al., 2004).IPM combines a range of biological, chemical and cultural methods to manage pathogen populations effectively,thus reducing reliance on chemical control means (Mahdy, 2002). The aim of this study is to test the efficacy of different methods including: chemical, biological, Systemic Acquired Resistance (SAR), plant extract and

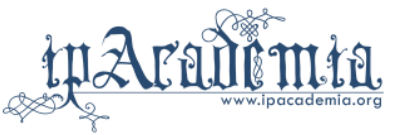


integrated management for controlling root-knot nematode Meloidogyne javanica on cucumber.

\section{MATERIALS AND METHODS}

For controlling $M$. javanica on cucumber plants under greenhouse conditions four materials have been selected including the nematicide Vydate 10L (a.i. = Oxamyl ) (manufacturing company: E.I.DUPONT DE NEMOURS \& COMPANY,USA) as chemical method, BioHealth® WSG (manufacturing company: HUMIN TECH, Germany) as biological method, Salicylic acid (manufacturing company Scharlau, Spain) as a method of Systemic Acquired Resistance (SAR) and ethanol extract of chili pepper fruit. Each material was applied individually and interacting with each other in bilateral interactions. Pots with a diameter of $19 \mathrm{~cm}$ and a depth of $18 \mathrm{~cm}$ were filled with sterilized sandy loam soil (17.63clay, 18.64 silt and $63.73 \%$ sand) by $3.5 \mathrm{~kg} /$ pot. Each pot was planted with 5 seeds of cucumber hybrid Sayff F1, which were eased after germination to keep 2 plants in each pot. Pots were placed randomly in the trenches ground (plunged) in a greenhouse at College of Agricultural Engineering Sciences in Semel / University of Duhok, Kurdistan Region-Iraq. The inner lining of the greenhouse was covered with tulle fabric carefully to avoid possible entry of insects.

\section{A. Extraction of nematode eggs}

Tomato plants Infected with $M$. javanica were uprooted from the pure cultures previously prepared and brought to the laboratory for extraction of $M$. javanica eggs by a method described by Coyne et al. (2007) and it was found that the mean number of eggs / $1 \mathrm{ml}$ of egg suspension and for 5 replications was 200 eggs.

\section{B. Application of control treatments}

After 16 days of cucumber planting $100 \mathrm{ml} /$ pot of the following treatments were applied to the soil before infesting with suspension of nematode eggs: 1 . Irrigation of soil with $1 \%$ Biohealth product (prepared with distilled water); 2. Irrigation of soil with $0.14 \%$ salicylic acid (prepared with distilled water). After 20 days of planting, seedlings were infested with nematode egg suspension at a rate of 3500 eggs / pot by making 3 holes depth of $3 \mathrm{~cm}$ around the plants with equal distances from each other. Then, the holes were covered with sterilized moist soil and the following treatments were applied; 3. Control treatment (1) without infesting soil by nematode suspension); 4. Control treatment (2) with infesting soil by nematode suspension; 5. Irrigation of soil with nematicide Vydate solution at concentration of $0.05 \%$ by $140 \mathrm{ml} /$ pot after a week of soil infestation; 6 . Irrigation of soil with $100 \mathrm{ml}$ of $1 \%$ biohealth / pot after a week of soil infestation; 7. Irrigation of soil with $100 \mathrm{ml}$ of $0.14 \%$ salicylic acid / pot after a week of soil infestation; 8 . Irrigation of soil with $100 \mathrm{ml}$ of $1.2 \%$ plant extract of ethanol pepper / pot after a week of soil infestation; 9. Irrigation of soil with $100 \mathrm{ml}$ of $1 \%$ Biohealth / pot after a week of applying salicylic as mentioned above; 10. Irrigation of soil with $100 \mathrm{ml}$ of $1 \%$ Biohealth / pot after a week of applying ethanol extract of chili pepper as mentioned above; 11 . Irrigation soil with $100 \mathrm{ml}$ of $1 \%$ Biohealth / pot after a week of Vydate application; 12. Irrigation soil with $100 \mathrm{ml}$ of $1.2 \%$ plant extract of ethanol pepper / pot after a week of applying salicylic acid as mentioned above; 13 . Irrigation soil with 140 $\mathrm{ml}$ of Vydate solution at concentration $0.05 \%$ after a week of applying ethanol extract of chili pepper as mentioned above; 14.Irrigation soil with $140 \mathrm{ml}$ of Vydate solution at concentration $0.05 \%$ after a week of applying salicylic acid as mentioned above.

All treatments were covered with a thin layer of moist sterilized soil. Plants were watered when needed and after 2 months of infestation, plants were uprooted carefully to calculate the following characters:

\section{- Plant growth criteria:}

1. Chlorophyll (SPAD) measured by chlorophyll meter (SPAD 502 / Konica Minolta Sensing, INC. made in Japan).

2. Shoot and root length ( $\mathrm{cm} /$ plant).

3. Fresh weight of shoot and root (gm/plant).

4. Dry weight of root and shoot system (gm/plant). Then the improvement percentage in growth criteria was calculated according to the fallowing equation:

Improvement percentage $(\%)=$ [Treatment - Control (infested soil) $] \div$ Control (infested soil) $\times 100$

\section{- Infection criteria:}

1. Number of root galls / root system of plant.

2. Root gall severity depending on galling index (GI) measure on $0-5$ scales and as follows: $(0=0,1=1-2,2=$ $3-10,3=11-30,4=31-100,5=$ more than 100 galls $/$ root system (Kumar et al., 2014).

3. Nematode population density in the soil for each pot by tray method as used by Kago et al. (2013).

4. Number of egg masses/root system by staining method as described by Stetina and Young, (2006).

5. Nematode population density/root system by staining method as follow: Cucumber roots were washed by tap water to remove soil. Then, roots were drained on paper towels and cut to $1 \mathrm{~cm}$. Next, roots were stained with red food color (Thies et al., 2002) by heating, then allowing it to cool to room temperature and washed under tap water. Egg masses and nematode inside the roots were counted using a stereomicroscope. Results were expressed as females per gram of root.

6. Number of eggs according to the method described by Coyne et al. (2007).

7. Rate of nematode reproduction according to the following equation:

Final population density $=$ Number of nematodes in soil + Number of nematodes in root + Number of eggs in root

Rate of reproduction $=$ Final population density of nematode $/$ initial population density of nematode.Then reduction 
percentage in infection criteria was calculated according to the fallowing equation:

Reduction percentage: $(\%)=[$ Control (infested soil) Treatment $\div$ Control (infested soil) $\times 100$.

\section{Experimental Design and Statistical analysis}

The experiment consisted of 14 treatments with 4 replications performed in CRD. Data were analyzed using SAS program to compare the means of studied characters depending on Duncan's multiple range test, $\mathrm{p} \leq 0.05$ ( SAS, 2001).

\section{RESUltS}

A. Effect of control methods used to control M. javanica on some growth criteria and chlorophyll content in leaves of cucumber plant

Statistical analysis indicate that root-knot nematode $M$. javanica caused significant reduction in all growth criteria of cucumber plants included fresh, dry weight and length of root and shoot system with chlorophyll content of leaves (Table1). Improvement was recorded in some mentioned characters which were significant in some treatments after application of nematicide Vydate, salicylic acid, biohealth, and ethanol extract of chili pepper individually and in bilateral interaction with each other as an integrated control.

Table 1. Effect of different methods used in controlling $M$. javanica on some growth criteria and leaves chlorophyll content of cucumber plants under greenhouse conditions.

\begin{tabular}{|c|c|c|c|c|c|c|c|}
\hline \multirow{2}{*}{$\begin{array}{l}\text { Growth Criteria } \\
\text { Treatments }\end{array}$} & \multicolumn{3}{|l|}{ Root system } & \multicolumn{4}{|l|}{ Shoot system } \\
\hline & $\begin{array}{c}\text { F.W. } \\
\text { (gm / plant) }\end{array}$ & $\begin{array}{c}\text { D.W. } \\
\text { (gm / plan) }\end{array}$ & $\begin{array}{c}\text { R.L. } \\
\text { (cm / plant) }\end{array}$ & $\begin{array}{c}\text { F.W. } \\
\text { (gm / plant ) }\end{array}$ & $\begin{array}{c}\text { D.W. } \\
\text { (gm / plant) }\end{array}$ & $\begin{array}{c}\text { S.L. } \\
(\mathrm{cm} / \text { plant })\end{array}$ & $\begin{array}{c}\text { Chl } \\
\text { ( SPAD) }\end{array}$ \\
\hline T1 = Pepper (A. I.) & $9.49 \mathrm{de}$ & $0.4725 \mathrm{bc}$ & $20.25 \mathrm{~cd}$ & $17.80 \mathrm{e}$ & $4.01 \mathrm{de}$ & $38 \mathrm{~d}$ & $22.01 \mathrm{a}$ \\
\hline T2=Salicylic acid (B.I.) & $10.06 \mathrm{cde}$ & $0.6250 \mathrm{bc}$ & $20.75 \mathrm{~cd}$ & $20.77 \mathrm{de}$ & $4.40 \mathrm{cde}$ & $40.75 \mathrm{~d}$ & $22.23 \mathrm{a}$ \\
\hline T3=Salicylic acid (A.I.) & 11 bcde & $0.73 \mathrm{bc}$ & $24 \mathrm{bcd}$ & $24.55 \mathrm{de}$ & 5.20 bcde & $43.75 \mathrm{~cd}$ & $22.37 \mathrm{a}$ \\
\hline T4= Biohealth (B.I.) & $11.75 \mathrm{bcd}$ & $0.79 \mathrm{abc}$ & $25.50 \mathrm{bcd}$ & 28.83 cde & $6.00 \mathrm{bcd}$ & $47.75 \mathrm{~cd}$ & $26.26 \mathrm{a}$ \\
\hline T5= Biohealth (A. I.) & $12 \mathrm{bcd}$ & $0.82 \mathrm{abc}$ & $25.75 \mathrm{bcd}$ & $37.27 \mathrm{bcd}$ & $6.12 \mathrm{bcd}$ & $50.25 \mathrm{bcd}$ & $26.41 \mathrm{a}$ \\
\hline T6=Vydate (A. I.) & $12.57 \mathrm{bc}$ & $0.85 \mathrm{abc}$ & 30 abcd & $48.45 \mathrm{ab}$ & $8.42 \mathrm{abc}$ & $53.25 \mathrm{abcd}$ & $27.55 \mathrm{a}$ \\
\hline T7=Pepper+Biohealth (A.I.) & $12.17 \mathrm{bcd}$ & $0.89 \mathrm{abc}$ & $27 \mathrm{bcd}$ & $41.84 \mathrm{abc}$ & $7.20 \mathrm{bcd}$ & $51.5 \mathrm{bcd}$ & $26.84 \mathrm{a}$ \\
\hline T8= Pepper+Vydate (A. I.) & $12.36 \mathrm{bcd}$ & $0.85 \mathrm{abc}$ & $28 \mathrm{bcd}$ & $45.58 \mathrm{ab}$ & $8.14 \mathrm{abc}$ & 52 bcd & $26.89 \mathrm{a}$ \\
\hline T9=Salicylic acid + pepper (A. I.) & $13.25 \mathrm{~b}$ & $0.93 \mathrm{abc}$ & $30.5 \mathrm{abcd}$ & $49.89 \mathrm{ab}$ & $8.45 \mathrm{abc}$ & 55 abcd & $28.88 \mathrm{a}$ \\
\hline T10=Salicylic acid+ Vydate (A. I.) & $14 \mathrm{~b}$ & $0.97 \mathrm{ab}$ & $32.50 \mathrm{abc}$ & $49.92 \mathrm{ab}$ & $9.21 \mathrm{ab}$ & $62 \mathrm{abc}$ & $29.53 \mathrm{a}$ \\
\hline T11=Salicylic acid + Biohealth (A. I.) & $14.018 \mathrm{~b}$ & $1.00 \mathrm{ab}$ & $35.75 \mathrm{ab}$ & $52.13 \mathrm{ab}$ & $9.24 \mathrm{ab}$ & $68.5 \mathrm{ab}$ & $29.78 \mathrm{a}$ \\
\hline T12=Vydate+Biohealth (A. I.) & $17.52 \mathrm{a}$ & $1.06 \mathrm{ab}$ & $36.25 \mathrm{ab}$ & $54.27 \mathrm{ab}$ & $9.30 \mathrm{ab}$ & $69 \mathrm{ab}$ & $31.25 \mathrm{a}$ \\
\hline T13=Just infestation (control ) & $8.49 \mathrm{e}$ & $0.29 \mathrm{c}$ & $18.50 \mathrm{~d}$ & $13.81 \mathrm{e}$ & $1.88 \mathrm{e}$ & $19.25 \mathrm{e}$ & $18.61 \mathrm{a}$ \\
\hline T14=Without infestation (control) & $18.72 \mathrm{a}$ & $1.43 \mathrm{a}$ & $41.50 \mathrm{a}$ & $56.035 \mathrm{a}$ & $11.73 \mathrm{a}$ & $72 \mathrm{a}$ & $32.7 \mathrm{a}$ \\
\hline
\end{tabular}

-Each value is a mean of 4 replications.

-The mean with different letters in each column are significantly differing according to Duncan's Multiple Range test (P $\leq 0.05)$.

-F.W. = Fresh weight, D.W. = Dry weight, R.L = Root length, S.L.= Shoot length, Chl= Chlorophyll content in leaves. B.I.= Before Infestation. A.I. = After Infestation.

It appears from the same table that using of biohealth after Vydate as bilateral treatment was more efficient compared to the other treatments where the values of the mentioned growth criteria and chlorophyll were $17.51 \mathrm{gm} / \mathrm{plant}, 1.06$ gm/plant, $36.25 \mathrm{~cm} /$ plant, $54.27 \mathrm{gm} /$ plant, $9.30 \mathrm{gm} / \mathrm{plant}$, $69 \mathrm{~cm} /$ plant and 31.25 SPAD correspondingly which means that this treatment caused an improvement in mentioned characters by $106.36,265.51,95.94,292.97,394.68,258.44$ and $67.92 \%$ respectively followed by using of biohealth after salicylic acid as bilateral treatment. On the other hand, the less efficient control treatment was in the ethanol extract of chili pepper application as a single treatment where the values of the same growth criteria and chlorophyll did not increased than $9.49 \mathrm{gm} /$ plant, $0.47 \mathrm{gm} /$ plant, $20.25 \mathrm{~cm} /$ plant, $17.80 \mathrm{gm} /$ plant, $4.01 \mathrm{gm} /$ plant, $38 \mathrm{~cm} /$ plant and $22.01 \mathrm{SPAD}$ respectively, thus the improvement percentage was 11.77,
$62.06,9.45,28.89,113.29,49.34$ and $18.26 \%$ for the same characters respectively (Table 2 ).

\section{B. Effect of some control methods of M. javanica on some} infection criteria in cucmber plants

Statistical analysis results showed that all control methods caused significant reduction in infection criteria included number of galls, root gall severity, number of egg masses,

number of nematode in root system, number of nematode in soil/pot, number of eggs, final population density of nematode and nematode reproduction rate in cucumber plants lanted in soil infested with $M$. javanica eggs as compared with control (infested soil) and with each other in certain cases (Table 3). 
Table 2. The resulting changes in growth criteria and chlorophyll content in leaves of Cucumber plants caused by root-knot nematode M.javanica compared with improvement changes resulted by different methods used in controlling this nematode.

\begin{tabular}{|c|c|c|c|c|c|c|c|}
\hline \multirow{3}{*}{ Growth Criteria } & \multicolumn{7}{|c|}{ Improvement \% } \\
\hline & \multicolumn{3}{|c|}{ Root system } & \multicolumn{4}{|c|}{ Shoot system } \\
\hline & $\begin{array}{c}\text { F.W. } \\
\text { (gm/ plant) }\end{array}$ & $\begin{array}{c}\text { D.W. } \\
\text { (gm / plan) }\end{array}$ & $\begin{array}{c}\text { R.L. } \\
\text { (cm/ plant) }\end{array}$ & $\begin{array}{c}\text { F.W. } \\
\text { (gm/plant) }\end{array}$ & $\begin{array}{c}\text { D.W. } \\
\text { (gm/plant) }\end{array}$ & $\begin{array}{c}\text { S.L. } \\
\text { (cm/plant) }\end{array}$ & Chl.(SPAD) \\
\hline T1= Pepper (A.I.) & 11.77 & 62.06 & 9.45 & 28.89 & 113.29 & 49.34 & 18.26 \\
\hline T2 = Salicylic acid (B.I.) & 18.49 & 113.79 & 12.16 & 50.39 & 134.04 & 111.68 & 19.45 \\
\hline T3 = Salicylic acid (A. I.) & 29.56 & 151.72 & 29.72 & 77.76 & 176.59 & 127.27 & 20.20 \\
\hline T4 = Biohealth (B.I.) & 38.39 & 172.41 & 37.83 & 108.76 & 219.14 & 148.05 & 41.10 \\
\hline T5 = Biohealth (A. I.) & 41.34 & 182.75 & 39.18 & 169.87 & 225.53 & 161.03 & 41.91 \\
\hline T6 = Vydate (A. I.) & 48.05 & 193.10 & 62.16 & 250.83 & 347.87 & 176.62 & 48.03 \\
\hline T7 = Pepper + Biohealth (A. I.) & 43.34 & 206.89 & 45.94 & 202.96 & 282.97 & 167.53 & 44.22 \\
\hline T8 = Pepper + Vydate (A. I.) & 45.58 & 193.10 & 51.35 & 230.05 & 332.97 & 170.12 & 44.49 \\
\hline T9 = Salicylic acid + pepper (A. I.) & 56.06 & 220.68 & 64.86 & 261.25 & 349.46 & 185.71 & 55.18 \\
\hline T10 = Salicylic acid + Vydate (A. I.) & 64.89 & 234.48 & 75.67 & 261.47 & 389.89 & 222.07 & 58.67 \\
\hline T11=Salicylic acid + Biohealth (A. I.) & 65.01 & 244.82 & 93.24 & 277.48 & 391.48 & 255.84 & 60.02 \\
\hline T12 = Vydate + Biohealth ( A. I.) & 106.36 & 265.51 & 95.94 & 292.97 & 394.68 & 258.44 & 67.92 \\
\hline
\end{tabular}

- Each value is an average of 4 replications.

- F.W.= Fresh weight, D.W. = Dry weight, R.L. = Root length, S.L. = Shoot length, Chl = Chlorophyll content in leaves. B.I.= Before Infestation. A.I.= After Infestation

Table 3. Effect of different methods used in controlling M. javanica on some infection criteria of cucumber plants under greenhouse conditions.

\begin{tabular}{|l|c|c|c|c|c|c|c|c|}
\hline \multirow{2}{*}{\multicolumn{1}{c|}{ Treatments }} & \multicolumn{9}{c|}{ Infection Criteria } \\
\cline { 2 - 8 } & N.O.G. & R.G.I. & E.M & N/ R & N/ S & N.O. E & F.P.D. & R.O.R \\
\hline T1=Pepper (A.I.) & $66 \mathrm{ab}$ & $4 \mathrm{ab}$ & $38 \mathrm{~b}$ & $1119.99 \mathrm{~b}$ & $2937.5 \mathrm{ab}$ & $6991.5 \mathrm{a}$ & $11040 \mathrm{~b}$ & $3.16 \mathrm{~b}$ \\
\hline T2=Salicylic acid (B.I.) & $62 \mathrm{bc}$ & $4 \mathrm{ab}$ & $36 \mathrm{~b}$ & $1089.37 \mathrm{~b}$ & $2875 \mathrm{ab}$ & $6720.54 \mathrm{~b}$ & $10684.9 \mathrm{bc}$ & $3.05 \mathrm{bc}$ \\
\hline T3=Salicylic acid (A.I.) & $58.5 \mathrm{bcd}$ & $4 \mathrm{ab}$ & $33 \mathrm{c}$ & $1057 \mathrm{~b}$ & $2750 \mathrm{abc}$ & $6561.5 \mathrm{~b}$ & $10368.5 \mathrm{c}$ & $2.96 \mathrm{c}$ \\
\hline T4=Biohealth (B.I.) & $53 \mathrm{bcde}$ & $4 \mathrm{ab}$ & $32 \mathrm{c}$ & $961.5 \mathrm{c}$ & $2625 \mathrm{abc}$ & $6262.5 \mathrm{c}$ & $9849 \mathrm{~d}$ & $2.81 \mathrm{~d}$ \\
\hline T5=Biohealth (A.I.) & $47 \mathrm{bcde}$ & $4 \mathrm{ab}$ & $28 \mathrm{~d}$ & $651.75 \mathrm{~d}$ & $2500 \mathrm{bcd}$ & $5813.5 \mathrm{~d}$ & $8965.3 \mathrm{e}$ & $2.56 \mathrm{e}$ \\
\hline T6=Vydate (A.I.) & $40 \mathrm{bcde}$ & $3.75 \mathrm{abc}$ & $21 \mathrm{f}$ & $615.24 \mathrm{def}$ & $1625 \mathrm{e}$ & $5577.82 \mathrm{e}$ & $7818.05 \mathrm{f}$ & $2.23 \mathrm{f}$ \\
\hline T7=Pepper + Biohealth (A.I.) & $46.75 \mathrm{bcde}$ & $3.75 \mathrm{abc}$ & $25 \mathrm{e}$ & $576.72 \mathrm{def}$ & $2375 \mathrm{~cd}$ & $5354.71 \mathrm{f}$ & $8306.4 \mathrm{f}$ & $2.37 \mathrm{f}$ \\
\hline T8=Pepper + Vydate (A.I.) & $44 \mathrm{bcde}$ & $4 \mathrm{ab}$ & $23 \mathrm{ef}$ & $637.19 \mathrm{de}$ & $2125 \mathrm{~d}$ & $5193.67 \mathrm{f}$ & $7955.9 \mathrm{f}$ & $2.27 \mathrm{f}$ \\
\hline T9=Salicylic acid + pepper (A.I.) & $32.75 \mathrm{bcdef}$ & $3 \mathrm{bc}$ & $16 \mathrm{~g}$ & $578.5 \mathrm{def}$ & $1250 \mathrm{ef}$ & $4853 \mathrm{~g}$ & $6681.5 \mathrm{~g}$ & $1.91 \mathrm{~g}$ \\
\hline T10=Salicylic aci+ Vydate (A.I.) & $27.5 \mathrm{cdef}$ & $3.25 \mathrm{bc}$ & $15 \mathrm{~g}$ & $540 \mathrm{ef}$ & $1187.5 \mathrm{f}$ & $4488 \mathrm{~h}$ & $6215.5 \mathrm{gh}$ & $1.77 \mathrm{gh}$ \\
\hline T11=Salicylic acid+Biohealth (A.I.) & $22 \mathrm{def}$ & $3 \mathrm{bc}$ & $13 \mathrm{gh}$ & $575.45 \mathrm{def}$ & $937.5 \mathrm{f}$ & $4355.37 \mathrm{~h}$ & $5868.3 \mathrm{hi}$ & $1.68 \mathrm{hi}$ \\
\hline T12=Vydate + Bioheath ( A.I.) & $20.25 \mathrm{ef}$ & $2.75 \mathrm{c}$ & $11 \mathrm{~h}$ & $524.72 \mathrm{f}$ & $875 \mathrm{f}$ & $4147.68 \mathrm{i}$ & $5547.4 \mathrm{i}$ & $1.58 \mathrm{i}$ \\
\hline T13=Just infestation & $97.25 \mathrm{a}$ & $4.5 \mathrm{a}$ & $72 \mathrm{a}$ & $2647.21 \mathrm{a}$ & $3062.5 \mathrm{a}$ & $7162.32 \mathrm{a}$ & $12872 \mathrm{a}$ & $3.68 \mathrm{a}$ \\
\hline T14=Without infestation (control) & $0 \mathrm{f}$ & $0 \mathrm{~d}$ & $0 \mathrm{i}$ & $0 \mathrm{~g}$ & $0 \mathrm{~g}$ & $0 \mathrm{j}$ & $0 \mathrm{j}$ & $0 \mathrm{j}$ \\
\hline
\end{tabular}

- Means with different letters in each column are significantly differ according to Duncan's Multiple Range test ( $\mathrm{P} \leq 0.05)$.

- Each mean is an average of 4 replications.

- N.O.G. $=$ Number of galls, R.G.I. $=$ Root gall index, E.M. $=$ Number of egg masses, N/R $=$ Number of nematode/root system, N/S $=$ Number of nematode/soil pot,

N.O.E. $=$ Number of eggs, F.P.D. $=$ Final population density of nematode, R.O.R. $=$ Rate of reproduction. B.I. $=$ Before Infestation. A.I. $=$ After Infestation

It was found from the same table that the use of biohealth after Vydate as a bilateral treatment has excelled in its impact on the other treatments where the lowest values of the infection criteria recorded which were 20.25 galls/root system, 2.75 gall index, 11 egg masses/root system, 524.72 nematodes/root system, 875 nematodes/soil pot, 4147.68 eggs/root system, 5547.4 final population density of nematode/pot and 1.58 reproduction rate/pot respectively, although the difference was not significant in most studied characters compared to some treatments (control methods). Thus the percentage of reduction caused by this treatment in the infection criteria reached $79.17,38.88,84.72,80.17$, $71.42,42.09,56.90$ and $57.06 \%$ respectively, this treatment was followed by bilateral treatment salicylic acid + biohealth in its effect on infection criteria except in the number of nematodes/root system where bilateral treatment salicylic acid + Vydate was excelled on its effect.

The least effective treatment in decreasing infection criteria was ethanol extract of chili pepper which recorded the highest values of the infection criteria (66 galls/root systemplant,4 gall index,38 egg masses/root system, 1119.99 nematodes/root system, 2937.5 nematodes/soil pot, 6991.5 eggs/root system, 11040 final population density/pot and 3.16 reproduction rate/pot respectively) compared to the other control methods (Table3) which means the reduction was in its minimum percentage which was $32.13,11.11,47.22$, $57.69,4.08,2.38,14.23$ and $14.13 \%$ for the same infection criteria correspondingly (Table 4). 
Ami \& Shingaly / Journal of Life and Bio-sciences Research Vol. 01, No. 02, pp. 44-50, (2020)

Table 4. Percentage of reduction in some infection criteria as a result of application of different methods used in controlling $M$. javanica of cucumber plant.

\begin{tabular}{|l|l|l|l|l|l|l|l|l|}
\hline \multirow{2}{*}{ Treatments } & \multicolumn{7}{|c|}{ Percentage of reduction rate in infection criteria \% } \\
\cline { 2 - 8 } T1= Pepper (A.I.) & 32.13 & 11.11 & 47.22 & 57.69 & 4.08 & 2.38 & 14.23 & 14.13 \\
\hline T2= Salicylic acid (B.I.) & 36.24 & 11.11 & 50 & 58.84 & 6.12 & 6.16 & 16.99 & 17.11 \\
\hline T3= Salicylic acid (A.I.) & 39.84 & 11.11 & 54.16 & 60.07 & 10.20 & 8.38 & 19.44 & 19.56 \\
\hline T4= Biohealth (B.I.) & 45.50 & 11.11 & 55.55 & 63.67 & 14.28 & 12.56 & 23.48 & 23.64 \\
\hline T5= Biohealth (A.I.) & 51.67 & 11.11 & 61.11 & 75.37 & 18.36 & 18.83 & 30.35 & 30.43 \\
\hline T6= Vydate ( A.I.) & 58.86 & 16.66 & 70.83 & 76.75 & 46.93 & 22.12 & 39.26 & 39.40 \\
\hline T7= Pepper + Biohealth (A.I.) & 51.92 & 16.66 & 65.27 & 78.21 & 22.44 & 25.23 & 35.46 & 35.59 \\
\hline T8= Pepper +Vydate (A.I.) & 54.75 & 11.11 & 68.05 & 75.92 & 30.61 & 27.48 & 38.19 & 38.31 \\
\hline T9= Salicylic + pepper (A.I.) & 66.32 & 33.33 & 77.77 & 78.14 & 59.18 & 32.24 & 48.09 & 48.09 \\
\hline T10=Salicylic acid +Vydate (A.I.) & 71.72 & 33.33 & 79.16 & 79.60 & 61.24 & 37.33 & 51.71 & 51.90 \\
\hline T11=Salicylic acid+Biohealth (A.I.) & 77.37 & 33.33 & 81.94 & 78.26 & 69.38 & 39.19 & 54.41 & 54.34 \\
\hline T12= Vydate + Bioheath (A.I.) & 79.17 & 38.88 & 84.72 & 80.17 & 71.42 & 42.09 & 56.90 & 57.06 \\
\hline
\end{tabular}

- Each mean is an average of 4 replications.

- N.O.G. = Number of galls, R.G.I. = Root gall index, E.M. = Number of egg masses, N/R = Number of nematode/root system, N/S = Number of nematode/soil pot, N.O.E. $=$ Number of eggs, F.P.D. $=$ Final population density of nematode, R.O.R. $=$ Rate of reproduction. B.I. $=$ Before Infestation. A.I. $=$ After Infestation

\section{DISCUSSION}

From the results it was clear that all control methods contributed in one way or another in improving growth indicators of cucumber plants infected with $M$. javanica depending on their efficiency in reducing nematode infection during their role in nematode suppression either in the soil or in the roots or both of them, and with respect to nematicide Vydate, these results are consistent with what have been found by Mostafa, (2001); Abo-Elyousr et al., (2010) and Khalil et al., (2012). The role of Vydate as a systemic carbamites nematicide is well known in eliminating nematodes and improving plant growth. The mechanism effect includes killing the nematodes in the soil due to weaken the nervous activity-muscle and reducing their movement then prevent root invasion due to the loss of sensitivity orientation towards the roots as well as killing of nematode stages in the roots, preventing its development and reproduction and inhibition of eggs hatching (Ahmed, 2008).

Regarding bio-agent (bio-health) (Trichoderma spp.), the efficacy of this fungus was due to its ability to resist the rootknot nematodes and decreasing infection then improvement of cucumber plant growth and this is what has been indicated by Mascarin et al. (2012) and Farfour and El-Ansary, (2013), the mechanism of the fungus includes its ability of parasitism on eggs of $M$. javanica causing egg shell rupturing by producing (secretion) of chitinase enzyme (Naserinasab et al., 2011; Izuogu, 2013; Lobna et al., 2016 ) and inhibition of root-knot nematodes by lytic enzymes (El-Nagdi and Abd-ElKhair, 2008) in addition to induction of plant defense which lead to systemic resistance (Radwan et al., 2011) besides the ability of this fungus in analyzing of soil nutrients and increasing their availability, which facilitates the absorption process by the root hairs (Izuogu et al., 2014) as well as its role in increasing the efficiency of plant growth by producing certain antibiotics (El-Shennawy et al., 2012). Whereas the positive impact of Bacillus sp. in improving growth indicators of plants infected by $M$. javanica and reducing infection criteria is consistent with results of previous studies (Masheva et al., 2016; Mokbel, 2013), this bacteria possess an ability of nematode parasitism (Khalil et al., 2012) which is attributed to the production of antibiotics and enzymes which are toxic to root-knot nematodes (such as glucanases, chitinases and proteases), which stimulate plant defenses and induced systemic resistance in plants (El-Shennawy et al., 2012), as well as releasing of nematicidal volatiles against nematodes (Radwan et al., 2011).

The effect of these bacteria also appear through the production of crystal objects which work as toxin (Khalil, 2013), decreasing the activity factors of egg hatching, solubilisation of mineral, production of phytohormones, inhibition the penetration of nematode into root, changing the root plant exudates, production of inhibitor substances and facilitate the absorption of nutrients (Karanja et al., 2007).On 
the other hand, the role of humic acid as one of the materials used within the contents of the bio-health in improving the plant growth parameters and reducing the infection criteria agree with previous studies (Scheuerell and Mahaffee, 2004; Zinovieva et al., 2011; El-Sherif et al., 2015). It was considered as alternative method to nematicidal application, induce plant defenses, increase the activity of chitinase enzyme (Abd El-Kareem, 2007), as well as it has been known that it increases the absorption of water and nutrients by roots and stimulates the plant growth which lead to increase plant cell division and increases photosynthesis (Chen et al., 2004; Al Hajiyat, 2015).

Results of salicylic acid in increasing plant growth criteria and decreasing the root-knot nematode development, agree with what have been found by Mukherjee et al. (2012); Mostafanezhad et al. (2014) and Moslemi et al. (2016). Mode of action of Salicylic acid includes in increasing the activity of enzymes in plant which are related to the defense of plant responses (e.g. catalase (CAT), phenylalanine ammonia lyase (PAL) and cytoplasmic peroxidase (POX) as found by Nikoo et al. (2014); Ogumo, (2014) and Al Hajiyat, (2015).These three enzymes play important role in biological processes of plants such as host-defense mechanisms, biosynthesis of lignin, and degradation pathways (Passardi et al., 2005 and Davies et al., 2008).In addition to that they induced Systemic Acquired Resistance of plants against nematodes (Siahpoush et al., 2011). Relating low efficiency of ethanol extract of chili pepper in nematode suppression compared to the other control methods agreed with Kepenekci et al. (2016) and its role may be attributed to its chemical composition such as allyl isothiocyanate, capsainoids and capsaicin which act as inhibitors for nematode activity in addition as nematicides (Mackeen et al., 1997 and Abbas et al., 2009).

\section{V.CONCLUSION}

Vydate + Biohealth as bilateral treatment was the most efficient treatment compared to the others for controlling root - knot nematode $M$.javanica on cucumber plants.

\section{REFERENCES}

Abbas, S., Dawar, S., Tariq, M. and Zaki, M.J. (2009). Nematicidal activity of spices against Meloidogyne javanica (Treub) Chitwood. Pakistan Journal of Botany, 41: 2625-2632.

Abd El-Kareem, F. (2007). Induced resistance in bean plants against root rot and alternaria leaf spot diseases using biotic and abiotic inducers under field conditions. Res. J. Agric. and Biol. Sci., 3(6): 767-774.

Abo-Elyousr, K.A., Khan, Z. and Abedel-Moneim, M. (2010). Evaluation of plant extracts and Pseudomonas for control of root-knot nematode, Meloidogyne incognita on tomato. Nematropica, 40(2): 289-299.

Ahmed, A.I. (2008). Cucumber root-knot nematodes disease in Erbil province and its certain control methods. M.Sc. thesis, College of Agriculture, University of Salahaddin, Erbil, Kurdistan Region- Iraq. (In Arabic).

Al Hajiyat, H.H.Y. (2015). Induction of resistance against citrus nematode Tylenchulus semipenetrans (Cobb, 1913) by using chemical and biological substance. M.Sc. thesis, College of Agriculture and forestry, University of Mosul, Iraq. (In Arabic).

Arora, R.; Battu, G.S. and Ramakrishnan, N. (2000). Microbial pesticides: current status and future outlook. In: Dhaliwal, G.S., Singh, B.(eds.), Pesticides and Environment. Commonwealth Publishers, New Delhi, pp. 344-395.
Azam, T., Hisamuddin, Robab, M.I. (2010). Effect of initial inoculation of Meloidogyne javanica on growth and yield of Lagenaria siceraria. Journal of American Science, 6: 617-622.

Chen, Y., De Nobili, M., Aviad, T. (2004). Stimulatory effect of humic substances on plant growth. In "Soil organic matter in sustainable agriculture" .(Eds. F. Magdoff, R.R. Weil).103-130, Boca Raton, FL.

Coyne, D.L., Nicol, J.M., Claudius-Cole, B. (2007). Practical plant nematology: a field and laboratory guide. International Institute of Tropical Agriculture (IITA).

Davies, M.J., Hawkins, C.L., Pattison, D.I., Rees, M.D. (2008). Mammalian heme peroxidases: from molecular mechanisms to health implications. Antioxidants and Redox Signaling, 10: 1199-1234.

El-Nagdi, W.M.A., Abd-El-Khair, H. (2008). Biological control of Meloidogyne incognita and Rhizoctonia solani in eggplant. Nematologia Mediterranea, 36(1):85-92.

El-Sayed, S.M., Mahdy, M.E. (2015). Effect of chitosan on root-knot nematode, Meloidogyne javanica on tomato plants. International Journal of Chem Tech Research, 7(4): 1985-1992.

El-Shennawy, M.Z., Khalifa, E.Z., Ammar, M.M., Mousa, E.M., Hafez, S.L. (2012). Biological control of the disease complex on potato caused by root-knot nematode and Fusarium wilt fungus. Nematologia Mediterranea, 40(2): 169-172.

El-Sherif, A.G., Gad, S.B., Khalil, A.M., Mohamedy, R.H.E. (2015). Impact of our organic acids on Meloidogyne incognita infecting tomato plants under greenhouse conditions. Global Journal of Biology, Agriculture and Health Sciences, 4(2):94-100.

El-Zawahry, A.M., Khalil, A.E.M., Allam, A.D.A., Mostafa, R.G. (2015). Effect of the Bio-agents (Bacillus megaterium and Trichoderma album) on Citrus Nematode (Tylenchulus semipenetrans) Infecting Baladi orange and Lime Seedlings. Journal of Phytopathology and Pest Management, 2(2): 1-8.

Farfour, S.A. and El-Ansary, M.S. (2013). Suppression of root-knot nematode (Meloidogyne incognita) on eggplant by applying some biofertilizers and biocontrol agents. Egyptian Journal of Agronematology, 12(1): 6373.

Hussain, M.A., Mukhtar, T., Kayani, M. Z. (2011). Assessment of the damage caused by Meloidogyne incognita on okra (Abelmoschus esculentus). The Journal of Animal and plant Sciences, 21(4): 857-861.

Izuogu, N.B. (2013). Nematicidal effect of Trichoderma harzianum T22 on Meloidogyne incognita (Kofoid and White) Chitwood, infecting Celosia argentea TLV8. J. Agri. Res. and Dev., 12(1):35-43.

Izuogu, N.B., Osuwa, O.V., Fabiyi, A.O., Olabiyi, T.I., Abolusoro, S.A. (2014). Field evaluation of Trichoderma harzianum T22 for the management of Meloidogyne incognita (kofoid and white) Chitwood on cowpea varieties. International Journal of Agricultural Sciences and Natural Resources, 1(1):7-12.

Kago, E.K., Kinyua, Z.M., Okemo, P.O., Maingi, J.M. (2013). Efficacy of Brassica Tissue and Chalim TM on Control of Plant Parasitic Nematodes. Journal of Biology, 1(1): 25-32.

Karanja, N.K., Mutua, G.K., Kimenju, J.W. (2007). Evaluating the effect of Bacillus and Rhizobium bio-inoculant on nodulation and nematode control in Phaseolus vulgaris L. In: Advances in Integrated Soil Fertility Research in Sub-Saharan Africa: Challenges and Opportunities, (Bationo, A., Waswa, B., Kihara, J., and Kimetu, J. eds.), Springer, Netherlands, 863-868 pp.

Kepenekci, İ., Erdoğuş, D., Erdoğan, P. (2016). Effects of some plant extracts on root-knot nematodes in vitro and in vivo conditions. Turkish Journal of Entomology, 40(1):3-14.

Khalil, M.S. (2013). The potential of five eco-biorational products on the reproduction of root-knot nematode and plant growth. International Journal of Phytopathology, 2(2): 84-91.

Khalil, M.S., Kenawy, A., Gohrab, M.A., Mohammed, E.E. (2012). Impact of microbial agents on Meloidogyne incognita management and morphogenesis of tomato. J Biopest, 5(1): 28-35.

Khan, T.A., Nasir, S., Ashraf, M.S. (2004). Effect of population levels of Meloidogyne javanica on plant growth and nematode multiplication on cucurbits. Pakistan Journal of Nematology, 22(1): 83-89.

Kumar, N., Adamu, M.A., Isah, K.M., Lawal, A.F. (2014). A Survey of vegetable fields for root-gall disease in Niger State, Nigeria. PAT, 10(1):17-27.

Lobna, H., Mayssa, C., Hajer, R., Naima, M.H.B., Ali, R., Najet, H.R. (2016). Biocontrol Effectiveness of Indigenous Trichoderma Species against 
Meloidogyne javanica and Fusarium oxysporum f.sp. radicis lycopersici on tomato. Biocontrol, 1, 50717, 1-5.

Mackeen, M.M., Ali, A.M., Abdullah, M.A., Nasir, R.M., Mat, N.B., Razak, A.R. and Kawazu, K. (1997). Antinematodal activity of some Malaysian plant extracts against the pine wood nematode, Bursaphelenchus xylohilus. Pesticide Science, 51:165-170.

Mahdy, M. (2002). Biological control of plant parasitic nematodes with antagonistic bacteria on different host plants. Ph.D. dissertation, Universitäts-und Landesbibliothek Bonn.

Mascarin, G.M., Junior, M.F.B. (2012). Trichoderma harzianum reduces population of Meloidogyne incognita in cucumber plants under greenhouse conditions. Journal of Entomology and Nematology, 4(6), 54-57.

Masheva, S., Yankova, V., Markova, D., Lazarova,T., Naydenov, M., Tomlekova, N., Sarsu, F., Dincheva, T. (2016). Use of microbioagents to reduce soil pathogens and root-knot nematodes in greenhouse-grown tomatoes. Bulgarian Journal of Agricultural Science, 22 (1): 91-97.

Mokbel, A.A. (2013).Impact of some antagonistic organisms in controlling Meloidogyne arenaria infecting tomato plants. Journal of Life Sciences and Technologies, 1(1):69-74.

Molinari, S., Loffredo, E.(2006). The role of salicylic acid in defense response of tomato to root-knot nematodes. Physiological and Molecular Plant Pathology, 68: 69-78.

Montasser, S.A., Abd El-Wahab, A.E., Abd-Elgawad, M.M.M., Abd-ElKhair, H., Faika, F.H.K., Hammam, M.M.A. (2012). Role of some plant extracts and organic manure in controlling Tylenchulus semipenetrans Cobb In Vitro And In Vivo In Citrus. Journal of Applied Sciences Research, 8: 5415-5424.

Moslemi, F., Fatemy, S., Bernard, F. (2016). Inhibitory effects of salicylic acid on Meloidogyne javanica reproduction in tomato plants. Spanish Journal of Agricultural Research, 14(1): 1-7.

Mostafa, F.A.M. (2001). Integrated control of root-knot nematodes, Meloidogyne spp. infecting sunflower and tomato. Pakistan Journal Biological Sciences, 4(1): 44-46.

Mostafanezhad, H., Sahebani, N. and Nourinejhad Zarghani, S. (2014). Induction of resistance in tomato against root-knot nematode Meloidogyne javanica with salicylic acid. Journal of Crop Protection, 3(4): 499-508.

Mukherjee, A., Babu, S.P.S., Mandal, F.B. (2012). Potential of salicylic acid activity derived from stress-induced (water) Tomato against Meloidogyne incognita. Archives of Phytopathology and Plant Protection, 45: 1909-1916.
Naserinasab, F., Sahebani, N., Etebarian, H.R. (2011). Biological control of Meloidogyne javanica by Trichoderma harzianum BI and salicylic acid on tomato. African Journal of Food Science, 5(3):276 - 280.

Nikoo, F.S., Sahebani, N., Aminian, H., Mokhtarnejad, L., Ghaderi, R. (2014). Induction of systemic resistance and defense-related enzymes in tomato plants using Pseudomonas fluorescens CHAO and salicylic acid against root-knot nematode Meloidogyne javanica. Journal of Plant Protection Research, 54(4): 383-389.

Ogumo, E. (2014). Use of eco-friendly strategies in suppression of root-knot nematodes in french bean (Phaseolus vulgaris) in Kenya. M.Sc. thesis, University of Nairobi.

Ohri, P., Pannu, S.K. (2010). Effect of phenolic compounds on nematodes- a review. Journal of Applied and Natural Science, 2(2): 344-350.

Passardi, F., Cosio, C., Penel, C., Dunand, C. (2005). Peroxidases have more functions than a Swiss army knife. Plant Cell Reports, 24: 255-265.

Radwan, M.A., Abu-ELamayem, M.M., Farrag, S.A.A., Ahmed, N.S. (2011). Integrated management of Meloidogyne incognita infecting tomato using bio-agents mixed with either oxamyl or organic amendments. Nematologia Mediterranea, 39(2):151-156.

SAS. (2001).SAS/STAT User, s Guide, Version 8.2, 1st printing.Vol.2.SAS Institute Inc, SAS Campus Drive, Gray, North Carolina.

Scheuerell, S.J. and Mahaffee, W.H. (2004). Compost tea as a container medium drench for suppressing seedling damping off caused by Pythium ultimum. Phytopathology, 94: 1156-1163.

Seid, A., Fininsa, C., Mekete, T., Decraemer, W., Wesemael, W.M. (2015). Tomato (Solanum lycopersicum) and root-knot nematodes (Meloidogyne spp.)-a century-old battle. Nematology, 17: 995-1009.

Siahpoush, S., Sahebani, N., Aminian, H. (2011). Change of some defense compounds of cucumber treated with Bacillus cereus and salicylic acid against Meloidogyne javanica. African Journal of Plant Science, 5: 829834.

Stetina, S.R., Young, L.D. (2006). Comparisons of Female and Egg Assays to Identify Rotylenchulus reniformis Resistance in Cotton. Journal of nematology, 38(3): 326-332.

Thies, J.A., Merrill, S.B., Corley, E.L. (2002). Red food coloring stain: New, safer procedures for staining nematodes in roots and egg masses on root surfaces. Journal of Nematology, 34(2):179-181.

Zinovieva, S. V., Vasyukova, N. I., Udalova, Zh. V., Gerasimova, N.G., Ozeretskovskaya, O.L. (2011). Involvement of Salicylic Acid in Induction of Nematode Resistance in Plants. Biology Bulletin, 38(5):453-458. 